\title{
Ontology of World Politics
}

\author{
Angela Khristin Brown \\ E-mail: brownlas6@aol.com
}

Received: 28-12-2013

Accepted: 26-01-2014

Published: 01-05-2014

doi:10.7575/aiac.ijalel.v.3n.3p.73

URL: http://dx.doi.org/10.7575/aiac.ijalel.v.3n.3p.73

\begin{abstract}
Culture division influences our lives differently in how we identify and evaluate who we are as individuals. We respond to life situations in how we interpret ourselves. How we function in society as a whole signifies invaluable differences in how we base our demeanor. Freedom of speech is a given right in American society. It is the social norm to be able to voice your opinion on diverse issues faced in our global environment. The Ontology of World Politics is a form of mediating issues of concern.
\end{abstract}

Keywords: Politics, Political Opinions, World Politics

\section{Introduction \& the Scenario}

I feel that racial profiling is wrong and discriminatory while being objected towards race and ethnicity. Often I hear on the radio how poor groups are harassed by police officers based on their race or Ethnicity. While groups are pulled over for suspension of being drug dealers because of the car they drive. It is unfair for the police to stereo type groups for being motivated and convicted of crimes they Did not comment. While groups are convicted of a crime for being hostile based on their demeanor. There have been reports of kids being murdered by police officers while defenseless. Racial profiling is wrong, while the people who actually doing the crime from other groups get fewer years in prison or are acquitted for the same crime. I feel tougher laws should be mandated when presented with cases like these. Affirmative action for state university enrollment is fair where no student admission should be denied. Students are admitted to college according to academic grades, activities, achievement score and academic program. Colleges want to enroll students that can do the work. Competition to being admitted in college is demanding the best students. Students of ethnic and race is a defining matter for creating diversity in school. Student athletes are required to have as much criterion as students with high academic criterion to being admitted in college. Affirmative action should only be admissible when student who reflect the enrollment demand and can create more diversity at the school.

It is important to promote property taxes on individual school districts for public schools, while many cities rely on their children attending public school. The overall cost for going to school is costly. Prerochrial school expenses rely on the church. There is a law that designates separation of church in state. Jim Crow laws after slavery did not permit all races and ethnic groups to attend public schools. Today, laws have changed and schools are more integrated. Bussing allows kids the opportunity to go to better schools or the choice to go to a local school near them. Bussing allows kids from different areas to attend public school and with this grants taxes on individual neighborhoods more affordable to parents. History classes should adapt to multicultural perspectives. I had one year of black history the twelve years in school. Within that year, I was taught Indian history, Nevada history, world and US history. Some feel that history is his - story and other races and ethnic groups are often disregarded and not taught as part of the curriculum. History covers a mainstream of multicultural values which should be addressed. If history is ignored and not taught in school, it will repeat. There are civic issues that go on in the news that the uneducated will never understand if they do not know the basis of what is going on.

The United States constitution permits freedom of religion. Thus religious observances should be recognized for Christians and non- Christians in school. There are a lot of ethnicity groups around the nation. Not all are of the same religious belief or background. No one should be denied a fair education based on their background, but on their ability to do the work well. There are schools designed for religious faith to grant a fair education to their group. Some cultures prefer to home school their children for accuracy in education. Schools should observe diverse religious belief as a standard.

I am appalled to some stereo types I view in the movies about race. The history of blacks in film evolved around with painted black faces. It evolved around with dark skinned as evil and light skinned as good. It evolved around with buck wheat on the Little Rascals or Amos and Andy. The stereo types for blacks were thought to be obedient and silly. Film today reflects blacks are drug dealers and drug addicts, gang members, prisoners, adulterers or film has changed to having positive roles by actors in some films like Tuskegee Men or television shows like Bill Cosby Show. I would hope that film ontinues to progress to the positive attributes of blacks.

Columbus did not discover America, America was salted by western Asians who first migrated here. Columbus discovered the West Indie islands. Columbus brought many European settlers to America under the direction of Queen Isabella, a teenage Spanish princess that resulted in the genocide on the American Indians tribes. Columbus mission was 
to prove the world was round by taking a short cut to Indian. The native Indians were got their name from a mistaken identity from the Indonesians. Because of Columbus many navigators and settlers came to America for personal freedoms. For discovering the new world that resulted in those freedoms, Columbus should be recognized.

I have experience several changes in history books throughout my life. As time passes, history changes and therefore; the books should impact changes. History should affect events and movements because nothing is the same. History is not ordinary. There are bits and pieces of history we do not understand and a lot we do not know and needs to be addressed. Making changes to these books addresses each position to reflect things going on. An education should not use books four years old on current history. History entails circumstance. Research should not be over four years old. As time change, education should become more challenging. Books are an important resource that is eminent to learning process.

Racial disparity should be discontinued. U.S. law says a person is innocent until proven guilty beyond doubt. It is sad when people are given the death penalty that is innocent. Recently; there was a case where a man was put to death thought to be innocent. As a young black male, Troy was put on trial for a rape case. Evidence showed he was innocent and his sermon did not match the woman who claimed he raped her. A town in Florida, committed genocide on a black town blaming an innocent black man for raping a white woman. The U.S. has a right to make reductions on the unlatch.

All government agencies should equip a multiracial staff to equate diverse issues within an entity. No one should discriminate against race or ethnicity. Effective hiring practices should allow diversity to educate problems is correct. A more diverse staff can come to a catharsis when creating programs and addressing problems that not everyone can understand. Prayer should be allowed in public schools when a student or government official dies. In Prerochrial School, we said prayer and our pledge allegiance to the flag every morning before class starts.

In public school, prayer was allowed when something scandalous or horrific was done. Not everyone believes in a Christian god. Not everyone believes in our government. Prayer should be observed for special times like when we are in war. Soldier pray before battle. Athletes pray before a gay. Prayer should be inclusive.

The Christian religion should play a role when teaching health and sex education in school. I was taught about contraceptives in health class. Catholics do not believe in using contraceptives, condoms, and birth control in any form. Public school taught me about abstinence and celibacy. Abstinence practice is to not have sex until you are ready. Catholics do not believe in having sex until after they are married. Public school taught me about celibacy. Celibacy means to having sex involves two esponsible adults. I believe that to wait to have sex until you are old enough to understand it, relationships and willing to take the responsibility to raise a child.

There is a history behind money, especially when you think of how a slave was sold for a chaise. People began to sell their sheep and other objects in replacement of money early on. In Africa, their daughter was sold for land or animal wealth. Later gold was used as a commodity. Nations could use gold to make jewelry. Nations started to trade for paper money. The value of a dollar had a gold strip inside the dollar. Paper had a value. Our nation writes on the dollar, "In God We Trust." To me the phrase is designating that there is a God.

I feel that faith based entities should all pay reattributes and punishment for all religious authorities that have sex with children. The religious leaders before working should have a background check for being child predators and medical test for being gay. The religious leaders are leaders in the church and should be more responsible and more accountable for their actions. There is sex abuse not only in the Catholic Church, but all churches.

The Constitution of the United States of America states that we believe in providing aid or government assistance to other countries during natural disasters and during unfair war. This is justifi able when those countries want our help. Like in Afghanistan, they don't want us there; we should let them fight their own battles. If like in Serial, where there is genocide, we should give help. If what happened in Thailand happens, we should give assistance. If like what happened in Haiti, we should help. What happened in 911 was a calling and warning we should have not have involvement with.

When our nation is at threat, we should take precaution. We should prepare ourselves for the threat for we are in crisis. We do not want them to build their army to attack our country. We do not want our country to be weak for attack. There was a need for breaking done our ally to protect our country from arsenal threat when threat still exists today.

We cannot give China too much trade power. China is believed our ally. China is a third world country. Trade policy with China should restrict their country when they believe in having unfair work policy such as slave trafficking or sex trafficking which is against our countries moral belief. When America starts to go outside our doctrine to practice outside common belief, it endangers everyone.

Military and war was originally predicated for men. It is the men who went to war and hunt, while the women cleaned and took care of the children. Today, women are allowed in the military; but are restricted to fight in combat. Men were thought to be stronger than women and less sensitive and so they can fight in wars. Women were allowed in the military during the World War, but they were taught etiquette skills on how to act like a lady. Military service should be restricted for combat.

The second wealthiest nation in the world is China. We borrowed from China, during our depression. China has the second wealthiest economy in the world. China has the second highest manufacturing country in the world. China has a high work ethic where their people believe in a good education and strive as a nation.

National testing is important for competition in America schools. National test show us where we stand in the country and around the world by reporting scores. Bush issued a law "No child left behind." This was an initiative to create 
standards in overall school achievements. This law raises the bar for students to meet expectations. National testing is good for schools to teach outside the box to make good students to award schools.

Tracking should be used in deterring courses for public school children and achievement scores should be used as a determining factor when deciding whether their child is good enough to attend their school. If entering an engineering school, students must know math. If attending the school of the arts, students must know the arts. If attending a magnet school, students must be advanced. If attending a culinary school, they must know the mechanics of cooking. If a student wants to become a nurse, students must be good in math and science. This is the reason behind tracking students to schools.

Funding for school should be a priority. Teachers often go beyond the call of duty by paying for items to help guide student instruction. Teachers are awarded for extradinary work by improving instruction. Schools are not funded when the students do not meet standards. The teachers who have access to instructional material can provide a better instruction and education, while the schools that lack this usually fall behind. If all schools had proper funding, there would be no child left behind.

Schools with fewer students per class are proven to give more attention to the student. Schools that have teacher assistants in large classes can help with the instruction process so all children are helped. In smaller classes, teachers can help every student in class by giving individual attention. With larger classes, there is not time to help every student's questions. The teacher is there to help student reach their educational goals. Every student is important and should not be over looked with a class of forty students in a class. There are benefits for home-school, public school and online students. Home-school students learn on that pace and are taught by their parents. Public schools are taught structured classes by a teacher.

Online classes are taught by the aid of a computer at their own pace. The benefits of home-school students, is that they do not experience peer pressure or educational stress being taught at home. Public school students can interact with their classmates to get help with assignments and questions they do not understand. Online students can conduct research and are more accountable for their education. However the discipline, students are held accountable for their education.

\section{Discussion}

Beauty is skin deep. Beauty is defined by the image you make of yourself and not what others lead you to believe. It is how you carry yourself and your self-image. Character can be beautiful. Words are only a measurement. From memories since a child, I encounter times where I question my beauty. As I grew older, I began to understand the nature behind being beautiful meant to me. There are several journeys that led me to this altercation, which were grief, love and loneliness. All of these matters, because of the pain I faced made me a better person. I can identify with self-hate through attempting suicide. Self-pity is a form of grief. It takes a lot of energy to feel lonely because you hate what you do not understand. Self-pity comes from wanting to accept love in your life, when you do not understand the best love is from those who mean it. Poverty nature's pity when one cannot afford nice things is controversial, hideous competition which ends up in denial and causes self-hate. During puberty, a child wants to be liked. Through peer pressure, you constantly want to be accepted by your peers and so you do things that will arouse the opposite sex, which makes loneliness the master of image. It is the image that you want to feel loved and cared for. Having your heart broken more than once and to move on is to face loneliness. It is from grief of losing a loved one is a burden we must carry to recognize our presence in life. To succeed in life we must subcome failure. An image becomes a menagerie for acceptance. Once a person feels loved, she can identify with what it means to love her image. Hate is painful. Love is happiness. One must find true happiness, in order to love oneself and this will be reached after full maturation. The feeling of grief, love and loneliness is defined by reason.

\section{Conclusion}

Individual growth determines character. We react to what motivates our actions. Our actions justify fate. We are accountable for what dictates an experience or desire to promote change.

\section{References}

Sherman, N. (1989). The Fabric of Character: Aristotle's Theory of Virtue. Oxford: Clarendon.

Sorabji, R. (1980), Aristotle on the Role of Intellect in Virtue', in Oksenberg Ame'lie Rorty (ed.), Essays on Aristotle's Ethics. Berkeley: University of California Press.

Virtue E. (-). A Critical Reader. Edinburgh: Edinburgh University Press.

Wiggins, D. (1980). Deliberation and Practical Reason, in Ame'lie Oksenberg Rorty (ed.), Essays on Aristotle's Ethics. Berkeley: University of California Press.

Jonathan, W. (2006). Journal compilation. Blackwell Publishing Ltd. 